\title{
Kebijakan Nasional Indonesia dalam Adaptasi dan Mitigasi Perubahan Iklim
}

\author{
Indonesian National Policy on Adaptation and Mitigation of \\ Climate Change
}

\author{
Wahyu Yun Santoso \\ Fakultas Hukum Universitas Gadjah Mada \\ Jln. Sosio Justisia, Bulaksumur, Yogyakarta, 55281, Indonesia \\ Tel./Fax:+62-274-512781E-mail:wahyu.yuns@ugm.ac.id
}

Submitted: Nov 8, 2015; Reviewed: Nov 22, 2015; Accepted: Dec 3, 2015

\begin{abstract}
From its arousal, the issue of climate change or global warming has become a distinct global trend setter in multidiciplinary discussion, including in the law perspective. Within legal discourse, the issue of climate change developed rapidly into several aspect, not only about adaptation nor mitigation, especially since the plurality of moral conviction relevant to the climate change facts. As a global matter, each country has the responsibility to adapt and mitigate with its own character and policy. This normative research aims to explore and describe in brief the Indonesian national policy in climate change adaptation and mitigation. Gradually, the contribution of Indonesia is getting firm and solid to the climate change regime, especially after the Bali Action Plan 2007.
\end{abstract}

Keywords: Adaptation; Mitigation; Climate Change; REDD

\begin{abstract}
Abstrak: Sejak pertama kalinya bergulir, isu perubahan iklim atau global warming telah menjadi trend setter tersendiri dalam wacana diskusi multidisipliner, termasuk dalam konteks hukum. Dalam diskursus ilmu hukum sendiri, isu perubahan iklim berkembang dalam sekian aspek pembahasan, terlebih dengan masih adanya banyak perdebatan yang terjadi mengenai penyebab maupun lingkup dampak dari perubahan iklim tersebut. Sebagai sebuah masalah global, tiap negara memiliki karakter tersendiri pada model kebijakannya dalam adaptasi dan mitigasi perubahan iklim. Penelitian ini bersifat normatif dan bertujuan untuk dapat memaparkan secara garis besar konsep kebijakan nasional Indonesia dalam adaptasi dan mitigasi perubahan iklim. Secara garis besar, Indonesia telah memberikan kontribusi cukup signifikan dalam rezim perubahan iklim, terutama pasca Bali Action Plan 2007.
\end{abstract}

Kata Kunci: Adaptasi; Mitigasi; Perubahan Iklim; REDD 


\section{PENDAHULUAN}

Perubahan iklim adalah fenomena global yang dipicu oleh kegiatan manusia terutama yang berkaitan dengan penggunaan bahan bakar fosil dan kegiatan alih-guna lahan. Fenomena perubahan iklim diawali dengan menumpuknya berbagai gas yang dihasilkan dari kegiatan tersebut pada atmosfer. Di antara gas-gas tersebut adalah Karbon Dioksida $\left(\mathrm{CO}_{2}\right)$, Metana $\left(\mathrm{CH}_{4}\right)$, dan Nitrous Oksida $\left(\mathrm{N}_{2} \mathrm{O}\right)$. Gas-gas tersebut memiliki sifat kekhususan seperti kaca yang bersifat meneruskan radiasi gelombang-pendek atau cahaya matahari, tetapi menyerap dan memantulkan radiasi gelombang-panjang atau radiasi-balik yang dipancarkan Bumi yang bersifat panas sehingga suhu atmosfer Bumi meningkat.

Dengan adanya penumpukan gas-gas tersebut, keadaan di dalam bumi identik dengan keadaan di dalam rumah kaca yang selalu lebih panas dibanding suhu udara di luarnya. Dari pemaknaan inilah, gas-gas tersebut dikenal dengan istilah "gas rumah kaca" dan pengaruh yang ditimbulkannya dikenal dengan istilah "efek rumah kaca". Dari proses alam inilah yang selanjutnya akan menimbulkan suatu pemanasan global yang akan berpengaruh terhadap perubahan iklim. ${ }^{1}$

Secara perhitungan matematis, fenomena pemanasan global memang bukan suatu proses instan yang terjadi dalam hitungan bulan atau belasan tahun, tetapi merupakan akumulasi secara bertahap dalam peningkatan konsentrasi kandungan gas rumah kaca di

United Nations Environment Programme (UNEP) and the Climate Change Secretariat (UNFCCC). (2002). Understanding Climate Change: a Beginner's Guide to the UN Framework Convention and Its Kyoto Protocol. Booklet UNEP-Jeneva. atmosfer Bumi. Proses yang lama dari pemanasan global ini membawa dampak bagi negara-negara di dunia, termasuk negara berkembang ikut merasakan akibatnya, namun tidak memiliki kemampuan yang memadai untuk melakukan adaptasi terhadap dampak negatif yang ditimbulkan oleh efek rumah kaca tersebut. Beberapa di antara dampak negatif tersebut adalah menurunnya produksi pangan, terganggunya fluktuasi dan distribusi ketersediaan air, penyebaran hama dan penyakit tanaman, serta dampak bagi kehidupan sosial ekonomi manusia.

Global Environment Outlook (bagian dari UNEP) melaporkan bahwa tingkat emisi "carbon dioxide" tahun 1990 mencapai 4 kali lipat tahun 1950 dan 65 juta hektar (dari 3500 juta hektar) hutan punah pada periode tahun 1990 - 1995, 70 persen sumber daya ikan di samudra 'over-fished' akibat 'overcapacity' armada penangkapan ikan yang mencapai 40 persen. IPCC memerediksi kenaikan temperatur mencapai 2,5 sampai 10,4 derajat celsius sampai periode seratus tahun mendatang dan permukaan laut telah mengalami kenaikan mencapai 9 inci dan diprediksi naik lagi antara 3,5 sampai 34,6 inci tahun $2010 .^{2}$

Data penelitian yang telah ada memerlihatkan tanda-tanda nyata perubahan iklim melalui parameter iklim yang berubah dalam jangka waktu tertentu. Telah terjadi kenaikan konsentrasi gas $\mathrm{CO}_{2}$ sebesar 265-285 ppm dari tahun 1750-1800 (sebelum Revolusi Industri) dan mencapai 365 ppm pada tahun 1996, serta diprediksi akan terus meningkat sampai lebih dari 600 ppm pada tahun $2100 .^{3}$

Ibid.

Ibid. 
Temperatur rata-rata permukaan bumi meningkat sebesar $0.3-0.6^{\circ} \mathrm{C}$ selama seratus tahun terakhir ini dan diprediksi akan meningkat sebesar $1.4-5.8^{\circ} \mathrm{C}$ dalam kurun waktu 1990-2100. Penelitian-penelitian juga menunjukkan bahwa terjadi kenaikan permukaan air laut sebesar 10-25 cm selama seratus tahun terakhir dan diprediksi akan meningkat sebesar 90-88 cm dalam 1990$2100 .^{4}$

Indonesia merupakan negara kepulauan dengan luas total daratan 1,9 juta kilometer persegi yang tersebar di 17.000 buah pulau. Sedangkan luas lautan sebesar 5,8 juta kilometer persegi termasuk zona ekonomi ekslusif. Ibukota negara dan hampir semua ibu kota provinsi terletak di wilayah pantai serta $65 \%$ penduduk tinggal di wilayah pesisir dengan panjang pantai total sekitar $81.000 \mathrm{~km}$. Kondisi geografis Indonesia yang merupakan negara kepulauan merupakan daerah yang rentan terhdap dampak perubahan iklim.

Sebagai negara yang notabene masih agraris, perubahan iklim akan menyebabkan gangguan pada daur air dan produksi pangan di Indonesia. Hujan yang intensitasnya semakin tinggi pada perioda musim hujan yang semakin pendek telah menyebabkan banjir di tempat-tempat yang tidak biasa. Penggundulan hutan telah memerparah permasalahan ini. Saat yang sama, penghutanan kembali dan pemeliharaan hutan yang masih ada bisa membantu beradaptasi dengan pola hujan dan daur air yang berubah ini. Namun demikian, permasalahan hutan telah menempati porsi pembahasan tersendiri di tingkat nasional.
Luas hutan Indonesia yang pada tahun 1950-an sekitar 162 juta hektar, di tahun 2000-an ini tinggal sekitar 98 juta hektar. Di masa "booming" pembangunan pada 1980-an, laju kehilangan hutan rata-rata 1 juta hektar per tahun. Kemudian meningkat menjadi 1.7 juta hektar/tahun pada dekade 1990-an dan saat ini Kementerian Kehutanan mencatat bahwa laju deforestasi adalah sebesar 2.8 juta hektar per tahun.

Berbagai bencana yang terkait dengan iklim seperti banjir-badai akibat gelombang pasang yang terjadi di Kepulauan Maluku sampai Kepulauan Sangihe dengan ketinggian $50 \mathrm{~cm}$ juga telah menambah keyakinan perubahan iklim telah terjadi, demikian pula menipisnya salju di Puncak Jaya-Papua atau makin panasnya kota-kota di Indonesia. ${ }^{5}$ Pengaruh pemanasan global yang menyebabkan perubahan iklim juga terlihat dari penurunan curah hujan di bawah normal sehingga masa tanam belum dapat dimaksimalkan seperti terjadi di Kalimantan Timur (Babulu Darat, Kota Bangun), Sulawesi Tenggara (Asera, Kendari), Lampung (Blambangan Umpu, Menggala). Sementara itu di sebagian wilayah Indonesia lainnya curah hujan meningkat sehingga menimbulkan banjir, genangan, dan tanah longsor seperti di Aceh Singkil, Medan, dan Mojokerto.

Naiknya permukaan air laut karena pemanasan global (global warming) dapat menyebabkan bencana besar bagi suatu pulau kecil dan membahayakan juga pendu-

\footnotetext{
Dalam beberapa data yang ditemukan melalui media internet, perubahan iklim diduga dan dipercayai memiliki keterkaitan dengan bermacam bencana yang semakin meningkat intensitasnya di Indonesia, termasuk juga perbedaan yang sangat mencolok dalam foto udara tentang glasier di Puncak Jaya Wijaya yang berkurang secara signifikan antara tahun $1997-2004$.
} 
duk yang tinggal di wilayah pesisir. Tenggelam atau hilangnya suatu pulau kecil merupakan salah satu fenomena yang akan pasti terjadi apabila dampak perubahan iklim tidak diindahkan. Dampak perubahan iklim bukan hanya akan dirasakan oleh wilayah pesisir saja akan tetapi juga dapat memengaruhi wilayah daratan yang berkaitan dengan perubahan musim tanam, kekeringan atau kemarau panjang, longsor dan banjir serta juga kebakaran hutan.

Saat Indonesia mengalami krisis lingkungan yang berkepanjangan, pemerintah Indonesia juga telah berhasil dengan sukses menyelenggarakan perhelatan akbar dunia dalam pembahasan tentang isu pemanasan global. Pertemuan para pemimpin dunia di Bali dalam perhelatan rutin UNFCCC Conference of the Parties (COP-13) itu telah menghasilkan beberapa keputusan tentang pengurangan emisi karbon sebagai bagian dari upaya adaptasi dan mitigasi terhadap perubahan iklim. Dalam "Bali Action Plan", di samping negara maju yang harus memenuhi kewajiban peningkatan target penurunan emisi dan membantu negara berkembang dalam upaya mengurangi dampak negatif perubahan iklim, ${ }^{6}$ negara berkembang juga didorong melakukan aksi nyata dalam upaya mitigasi dan adaptasi terhadap perubahan iklim dalam konteks pembangunan berkelanjutan, antara lain melalui integrasi upaya adaptasi dan mitigasi perubahan iklim ke dalam perencanaan nasional dan sectoral planning. ${ }^{7}$

Masyarakat yang mendiami suatu daerah rentan perubahan iklim, sebagaimana

Dalam tiga hal utama, yaitu: capacity building, technology transfer dan financial.

Ibid. halnya Indonesia, harus melakukan suatu upaya adaptasi untuk mengatasi masalah yang terjadi. Mengingat hal tersebut, langkah antisipatif akan lebih efektif dan biaya yang dikeluarkan akan lebih rendah bila dibanding dengan upaya adaptasi yang dilakukan nanti pada saat keadaan sudah semakin memburuk dimana dampak sudah semakin besar sehingga upaya adaptasi akan membutuhkan biaya lebih mahal.

Sampai saat ini, kebijakan nasional tentang pengembangan dan pelaksanaan rencana serta upaya adaptasi belum secara eksplisit tertuang di dalam kebijakan sektor-sektor yang terkait dengan perubahan iklim, seperti sektor energi, perhubungan, pertanian, kehutanan dan kesehatan. Pada umumnya kebijakan sektor hanya menyinggung upaya yang mengarah pada rencana maupun upaya adaptasi, tapi belum terfokus pada pengembangan dan pelaksanaan rencana dan upaya adaptasi terhadap perubahan iklim, sebagaimana yang dimaksud dalam Konvensi Perubahan Iklim. Meskipun perlu untuk menjadi catatan tersendiri, bahwa permasalahan perubahan iklim merupakan suatu isu yang interdimensional, sehingga akan terlalu banyak aspek yang bisa menjadi bahan pembicaraan.

Dalam kerangka alur usulan penelitian ini, pembahasan mengenai konsep adaptasi dan mitigasi perubahan iklim, nantinya akan lebih menitikberatkan pada permasalahan terkait dengan flexible mechanisms yang dapat diterapkan oleh negara berkembang seperti berkembang -dalam hal ini melalui CDM ataupun mekanisme lain yang dapat diterapkan dalam hal perdagangan emisi 
karbon ${ }^{8}$; permasalahan upaya pengurangan dampak global warming melalui reforestasi (skema REDD) ${ }^{9}$; serta upaya mitigasi yang perlu dan dapat diterapkan untuk wilayah pesisir dan kepulauan, seperti Indonesia. Demikian juga dengan skema REDD+ yang diusulkan oleh Indonesia saat ini, belum menampakkan kejelasan konsep riil untuk aktualisasinya.

\section{METODE}

Penelitian dengan tema "Kebijakan Nasional Indonesia dalam Adaptasi dan Mitigasi Perubahan Iklim" ini merupakan penelitian hukum normatif. Bahan penelitian yang digunakan pada penelitian hukum normatif adalah bahan hukum primer yang terdiri dari peraturan perundang-undangan yang terkait dengan perubahan iklim (climate change),

8 Di dalam UNFCCC, negara berkembang tidak memiliki kewajiban mutlak untuk mengurangi emisi karbon seperti halnya Negara Annex I, akan tetapi juga memiliki kewajiban untuk ikut berpartisipasi aktif. Dalam hal ini terdapat mekanisme yang diperuntukkan untuk negara berkembang (non-Annex I parties) untuk ikut mengurangi tingkat emisi karbon melalui Clean Development Mechanism. Namun demikian, dalam perkembangannya akhir-akhir ini, mulai semakin bias juga pewacanaan di dalam media publik mengenai Carbon Trading, di mana seolah-olah negara berkembang memiliki kewajiban yang sama dalam hal ini.

REDD ataupun Reduced Emission from Deforestation and Degradation in developing countries merupakan suatu mekanisme yang memungkinkan negara dengan tingkat populasi hutan yang masih cukup banyak untuk dapat memberikan kontribusi riil di dalam pengurangan emisi karbon. Peluang yang sangat besar ini masih terkendala karena belum siapnya suatu kerangka hukum yang jelas maupun juga alur mekanisme dalam pelaksanaannya. Di sisi lain, beberapa pihak - terutama dari negara berkembang - masing menyangsikan tentang "kemurnian" niat dari Negara Maju (Annex I) dalam pengurangan emisi karbon melalui reforestasi ini. Salah satu bentuk kesangsian ini nampak pada isu tentang ketidakadilan dari skema REDD karena ekuivalen dengan pembolehan pembuangan emisi di negara maju selama melakukan peremajaan dan pelestarian hutan di negara berkembang yang notabene memiliki cukup banyak ekosistem hutan. lingkungan, serta kehutanan. Bahan hukum sekunder berupa bahan pustaka seperti buku, jurnal, hasil penelitian, makalah dan dokumen-dokumen lainnya yang terkait dengan penelitian ini, sedangkan bahan hukum tersier berupa bahan hukum yang memberikan kelengkapan informasi tentang bahan hukum primer dan bahan hukum sekunder seperti kamus hukum dan kamus bahasa.

Bahan penelitian yang didapat diklasifikasikan sesuai dengan pokok bahasan dan selanjutnya data yang didapat dianalisis secara kualitatif yaitu sesuai dengan kualitas kebenarannya kemudian dituangkan dalam bentuk deskripsi yang menggambarkan tentang penerapan pendekatan kehati-hatian sebagai upaya protektif atas komersialisasi sumber daya genetik. Dengan demikian, dapat diperoleh gambaran yang menyeluruh mengenai jawaban atas rumusan permasalahan yang diajukan.

\section{ANALISIS DAN PEMBAHASAN}

\section{Kerangka Pengaturan Internasional ten- tang Perubahan Iklim}

Peningkatan konsentrasi Gas Rumah Kaca (GRK) yaitu $\mathrm{CO}_{2}, \mathrm{CH}_{4}, \mathrm{~N}_{2} \mathrm{O}, \mathrm{SF}_{6}$, $\mathrm{HFC}$ dan PFC akibat aktivitas manusia menyebabkan meningkatnya radiasi yang terperangkap di atmosfer. Hal ini menyebabkan fenomena pemanasan global yaitu meningkatnya suhu permukaan bumi secara global. Pemanasan global mengakibatkan perubahan iklim, berupa perubahan pada unsur-unsur iklim seperti naiknya suhu permukaan bumi, meningkatnya penguapan di udara, berubahnya pola curah hujan dan tekanan udara yang pada akhirnya akan mengubah pola iklim 
dunia. ${ }^{10}$ Pemanasan global dan perubahan iklim terutama terjadi akibat aktivitas manusia misalnya pemanfaatan bahan bakar fosil, kegiatan pertanian dan peternakan, atau dikarenakan konversi lahan yang tidak terkendali.

Konvensi Perubahan Iklim atau UNFCCC (United Nations Framework Convention on Climate Change) adalah sebuah kesepakatan yang bertujuan untuk menstabilkan konsentrasi gas rumah kaca (GRK, atau Green House Gas-GHG) di atmosfir, pada taraf yang tidak membahayakan kehidupan organisme dan memungkinkan terjadinya adaptasi ekosistem, sehingga dapat menjamin ketersediaan pangan dan pembangunan berkelanjutan. ${ }^{11}$

Negara-negara yang telah meratifikasi konvensi harus berupaya menekan laju peningkatan emisi GRK di dalam negerinya. Namun pada konvensi ini dikenal adanya prinsip "common but differentiated responsibilities", dimana setiap negara memiliki tanggung jawab yang sama namun dengan peran yang berbeda-beda. Protokol Kyoto yang lahir tahun 1997 pada periode komitmen pertama I (2008-2012) menyebutkan bahwa negara-negara maju (dalam Konvensi disebut Annex-I countries, negara yang mengkontribusikan GRK dalam jumlah yang signifikan) diwajibkan untuk menurunkan emisinya. Hal ini tidak berlaku bagi negara-negara berkembang (Negara NonAnnex-I). ${ }^{12}$

Sejarah perkembangan isu perubahan iklim dimulai pada tahun 1979

10 Supra No. 1

11 IPPC, Fourth Assessment Report: Climate Change 2007. Available online at: http://www.wmo.ch/ pages/partners/ipcc/index en.html.

12 Ibid. dengan diadakannya The First World Climate Conference yang mengidentifikasi perubahan iklim sebagai sebuah permasalahan global sangat mendesak dan mengeluarkan deklarasi untuk mengundang pemerintah di seluruh dunia untuk mengantisipasinya. Hal ini ditindaklanjuti dengan pembentukan World Climate Programme dengan arahan World Meteorological Organization (WMO), United Nations Environment Programme (UNEP) dan International Council of Scientific Unions (ICSU) serta diikuti penyelenggaraan konferensi intergovernmental dalam isu perubahan iklim. ${ }^{13}$

Pada tahun 1988 dilangsungkan debat dalam Toronto Conference on the Changing Atmosphere ketika lebih dari 340 peserta debat dari 46 negara merekomendasikan untuk membentuk comprehensive global framework convention sebagai upaya perlindungan atmosfer. Mengikuti proposal yang diajukan Malta, UN General Assembly menyampaikan isu perubahan iklim untuk pertama kalinya dengan mengadopsi Resolution 43/53. WMO dan UNEP membentuk Intergovernmental Panel on Climate Change (IPCC), untuk mengkaji perubahan dunia yang telah terjadi, memperkirakan dampak yang ditimbulkannya dan mengajukan strategi untuk menanggulanginya. ${ }^{14}$

Pada medio 1990 IPCC mempublikasikan "First Assessment Report on the State of the Global Climate”, yang menjadi dasar negosiasi di bawah United Nations General

13 Sands, Philippe. (2003). Principle of International Environmental Law: Second Edition, Cambridge UK: Cambridge University Press, hlm. 141

14 Faure, Michael., Gupta, Joyeeta. and Nentjes, Andries (ed.). (2003). Climate Change and the Kyoto Protocols: the Role of Institution and Instrument to Control Global Change, Glos UK: Edward Elgar Publishing Ltd., hlm. 56 
Assembly on a Climate Change Convention. Tanggal 21 Desember 1990 UN General Assembly melalui Resolution 45/212 membentuk Intergovernmental Negotiating Committee for a Framework Convention on Climate Change (INC) sebagai "the single intergovernmental negotiating process under the auspices of the General Assembly". Pertemuan INC berlangsung dalam lima sesi dalam selang waktu antara Februari 1991 dan Mei 1992. ${ }^{15}$

Intergovernmental Negotiating Committee for a Framework Convention on Climate Change (INC) menyelesaikan teks konvensi dalam waktu 15 bulan dan diadopsi di New York pada tanggal 9 Mei dan dilaunching pada Juni di Rio de Janeiro Earth Summit, dimana UNFCCC dibuka untuk penandatanganan dan 154 negara menandatanganinya. Konvensi ini mulai berlaku tanggal 21 Maret 1994.

Pertemuan Para Pihak (Conference of the Parties) pertama dilaksanakan pada 1995 di Berlin (COP-1 Berlin). INC menyelesaikan tugasnya untuk mempersiapkan implementasi konvensi. Parties menyetujui komitmen untuk negara-negara industri dan menghasilkan "Berlin Mandate" yang menyebutkan tentang komitmen tambahan. Hasil COP1 adalah membentuk Ad Hoc Group on the Berlin Mandate untuk menindaklanjuti negosiasi; dan memutuskan perlunya dilakukan pertemuan Subsidiary Body for Implementation $^{16}$ dan Subsidiary Body for Scientific and Technological Advice ${ }^{17}$.

Pertemuan selanjutnya dilaksanakan di Genewa Swiss pada tahun 1996 (COP-2

\footnotetext{
15 Ibid

16 Pasal 10 UNFCCC

17 Pasal 9 UNFCCC
}

Geneva). Pada tahun 1997 COP-3 di Kyoto mengadopsi Kyoto Protocol. Protokol ini menciptakan target individual (dan terikat secara hukum) bagi negara-negara industri untuk mempersiapkan langkah-langkah positif dalam menurunkan emisi $\mathrm{CO} 2$ dan GHG lainnya. Satu tahun setelah Kyoto dilaksanakan pertemuan di Buenos Aires, Argentina pada tahun 1998 di COP-4. Pada acara ini dihasilkan Buenos Aires Plan of Action $(B A P A)$, yaitu rencana dua tahun untuk menyelesaikan perangkat praktis implementasi Konvensi. ${ }^{18}$

Pertemuan selanjutnya berturut-turut dilaksanakan di Bonn, Jerman (COP-5) pada 1999; COP-6 di the Hague, the Netherlands pada 2000; dan 2001 di Bonn lagi yang merupakan pertemuan khusus (COP 6.5) di mana dihasilkan Bonn Agreement tentang sistem perdagangan emisi, Clean Development Mechanism (CDM), aturan untuk menghitung reduksi emisi dari carbon sinks, dan compliance regime. Selain itu juga menggarisbawahi paket dukungan keuangan dan teknologi untuk membantu Negara berkembang agar dapat berkontribusi dalam aksi global perubahan iklim dan dampaknya. Pertemuan COP-7 2001 di Marrakech melahirkan Marrakech Accords yang merupakan finalisasi teknis secara rinci mengenai Bonn Agreement terkait Kyoto Protocol. ${ }^{19}$

Pertemuan COP-8 di New Delhi India merupakan sesi pertama yang dilakukan setelah penyelesaian negosiasi di bawah BAPA. COP8 mengadopsi Delhi Ministerial Declaration on Climate Change and Sustainable Development dan New Delhi Work

\footnotetext{
18 IPPC, Fourth Assessment Report: Climate Change 2007.

19 Ibid.
} 
Programme dalam aspek pendidikan, training dan public awareness. Pertemuan selanjutnya diadakan di Milan Italy pada 2003 yang merupakan COP-9 dan mengadopsi keputusan kegiatan afforestasi dan reforestasi di bawah skema CDM. Sedangkan pertemuan COP-10 tahun 2004 kembali diadakan di Buenos Aires yang membahas adaptasi perubahan iklim dan menghasilkan Buenos Aires Programme of Work on Adaptation and Response Measures. ${ }^{20}$

Conference of Parties (COP), yang berperan sebagai 'supreme body' dan otoritas tertinggi dalam pembuatan keputusan Konvensi Perubahan Iklim, merupakan pertemuan tahunan yang mengumpulkan semua negara pihak (parties) anggota konvensi. COP bertanggung jawab untuk mengkaji ulang implementasi konvensi dan instrumen legal lainnya terkait dengan konvensi, selain itu juga COP harus membuat keputusan yang diperlukan untuk meningkatkan efektivitas implementasi konvensi. ${ }^{21}$

Extraordinary COP dapat diselenggarakan apabila dirasakan urgensinya atau adanya Submission Negara pihak secara tertulis dan didukung oleh setidaknya sepertiga dari jumlah total parties dalam jangka waktu enam bulan. Extraordinary COP ini dilangsungkan tidak lebih dari 90 hari setelah permintaan tersebut menerima dukungannya (seperti pada COP6).

Sesi pertemuan COP pada umumnya berjalan selama dua minggu dan dilakukan paralel dengan sesi Subsidiary Body for Scientific and Technological Advice (SBSTA) dan Subsidiary Body for Implementation

\footnotetext{
20 Ibid.

1 Sands, Philippe. 2003, Op. Cit.
}

(SBI), yang dihadiri oleh ribuan peserta termasuk delegasi pemerintah dan observer. Tanggal penyelenggaraan COP biasanya selalu diumumkan pada sesi awal pertemuan sebelumnya, berlokasi di Sekretariat UNFCCC yang berkedudukan di Bonn-Jerman kecuali adanya penawaran dari parties untuk menjadi tuan rumah. Sejak COP-II di Montreal- Kanada bulan Desember 2005, karena Protokol Kyoto sudah berlaku secara hukum (Entry into force), pelaksanaan COP selalu dilaksanakan secara bersamaan dengan COP/MOP.

Berdasarkan Artikel 13 Protokol Kyoto, parties yang telah meratifikasi protokol akan bertemu dalam Conference of Parties serving as Meeting of Parties to the Kyoto Protocol(COP/MOP) yang dilangsungkan bersamaan dengan COP. Parties yang tidak meratifikasi protokol dapat hadir sebagai Observer dalam COP/MOP akan tetapi tidak memiliki hak suara dalam pengambilan keputusan. Dalam COP/MOP1 tahun 2005 dihasilkan salah satu keputusan penting, yaitu "Consideration of commitments for subsequent periods for Annex I Parties to the Convention under Article 3.9 of the Kyoto Protocol" (decision 1/CMP.1), dimana parties memutuskan untuk mempertimbangkan komitmen lanjutan dari Annex-I untuk periode setelah 2012. Hal ini mendorong pembentukan Ad-Hoc Working Group of Parties to the Kyoto Protocol ( $A W G$ ) untuk menindaklanjutinya dan akan dilaporkan kepada COP/MOP. ${ }^{22}$

Protokol Kyoto mulai berlaku sejak 16 Februari 2005 dengan disepakatinya ratifikasi Protokol oleh Majelis Rendah (DUMA)

\footnotetext{
22 Ibid.
} 
Rusia dan pada penyelenggaraan COP-11 di Montreal Canada dilangsungkan pula first Conference of the Parties Serving as the Meeting of the Parties to the Kyoto Protocol (COP/MOP1), dengan terobosan politis untuk memulai suatu dialog tentang strategic long-term cooperative action. Sampai dengan bulan September 2006, 189 negara dari total anggota UN (191 negara), dan European Community (EU) bergabung dalam Konvensi Perubahan Iklim (164 negara dan EU bergabung dalam Kyoto Protocol). ${ }^{23}$ Hal ini menunjukkan secara jelas bahwa Konvensi Perubahan Iklim merupakan satu persetujuan internasional yang ada yang memperoleh dukungan paling banyak dari seluruh dunia.

\section{Protokol Kyoto dan Clean Development Mechanisms}

Proses panjang lahirnya Protokol Kyoto berawal dari dihasilkannya Konvensi Kerangka Kerja Perserikatan Bangsa-bangsa tentang Perubahan Iklim (United Nations Framework Convention on Climate Change, UNFCCC) pada tahun 1992 di Rio de Janeiro, Brasil. Konvensi ini didukung oleh masyarakat internasional secara luas karena disadari bahwa UNFCCC dapat merupakan landasan yang cukup kuat bagi penerapan tindakan konkret di masa mendatang dalam mengatasi permasalahan perubahan iklim di dunia. Sebagai sebuah instrumen hukum (legal instrument) Protokol Kyoto disusun untuk mengimplementasikan Konvensi Perubahan Iklim dengan tujuan menstabilkan konsentrasi gas rumah kaca agar tidak mengganggu sistem iklim Bumi.

23 IPPC, Fourth Assessment Report: Climate Change 2007.
Protokol Kyoto diadopsi pada tanggal 11 Desember 1997 dan mulai dibuka untuk ditandatangani pada tanggal 16 Maret 1998. Protokol Kyoto akan berlaku secara efektif 90 (sembilan puluh) hari setelah diratifikasi oleh paling sedikit 55 negara Pihak Konvensi, termasuk negara maju dengan total emisi karbon dioksida paling sedikit 55 persen dari total emisi tahun 1990 dari kelompok industri ini. ${ }^{24}$ Efektivitas Protokol Kyoto yang disyaratkan tersebut menunjukkan pentingnya peranan negara-negara di dunia, baik negara berkembang maupun negara maju sebagai pihak pengemisi utama.

Berdasarkan Laporan Sidang Ketiga Konferensi Para Pihak ${ }^{25}$ yang tercantum pada tabel terakhir lampiran Protokol Kyoto menunjukkan persentase kontribusi emisi terbesar dari negara di dunia. Negara yang selama ini memberikan kontribusi terbesar dalam peningkatan konsentrasi gas rumah kaca secara persentase dimulai dari Amerika Serikat $(36,1)$, kemudian Rusia $(17,4)$, Jepang $(8,5)$, Jerman $(7,4)$, Inggris $(4,2)$, Kanada $(3,3)$, Italia $(3,1)$, Polandia (3), Prancis $(2,7)$, Australia $(2,1)$, empat negara antara $1-2$ persen, 17 negara di bawah 1 persen, dan sisa tiga negara 0 persen.

Negara-negara maju yang di dalam sejarahnya telah lebih awal mengkontribusi gas rumah kaca ke atmosfer menjadi pihak yang tercantum dalam Negara Annex I. Negara-negara ini wajib menurunkan emisinya, sedangkan negara non-Annex I tidak dikenakan kewajiban ini. Yang termasuk negara Annex I: Amerika Serikat, Australia, Austria, Belanda, Belarusia, Belgia, Bul-

\footnotetext{
24 Pasal 25 Protokol Kyoto

25 Tabel terakhir yang terlampir pada Protokol Kyoto setelah Annex A dan Annex B
} 
garia, Cheko, Denmark, Estonia, Eslandia, Finlandia, Federasi Rusia, Jerman, Hongaria, Irlandia, Italia, Inggris, Jepang, Kanada, Kroasia, Latvia, Liechtenstein, Lithuania, Luxemberg, Monako, Norwegia, Polandia, Portugal, Perancis, Rumania, Selandia Baru, Slowakia, Slovenia, Spanyol, Swedia, Swiss, Turki, Ukrania, dan Yunani.

Protokol Kyoto dapat dikatakan sebagai suatu traktat lingkungan hidup dunia yang paling rumit dan paling ambisius karena mengharuskan 39 negara industri dunia, termasuk Jepang dan Eropa, untuk mengurangi produksi enam gas rumah kaca, terutama karbon dioksida, dengan sedikitnya 5,2 persen sebelum tahun 2012. Hal inilah yang kemudian menjadi sumber permasalahan berlarutnya implementasi Protokol Kyoto. Beberapa negara maju seperti AS dan Australia ikut dalam bilangan pihak yang oposan terhadap Protokol Kyoto. Penolakan ini didasari alasan bahwa penerapan Protokol Kyoto akan merugikan sektor perekonomian negara maju, serta pendapat agar negara berkembang juga menerapkan ketentuan yang sama dengan yang ditentukan bagi negara maju.

Satu negara pihak yang cukup signifikan pengaruhnya dalam penerapan Protokol Kyoto adalah Rusia. Rusia pada awalnya mengikuti jejak Amerika Serikat dan sejumlah negara maju yang menganggap pelaksanaan Protokol Kyoto akan memberatkan industri karena mensyaratkan pengurangan emisi karbon dioksida sampai pada kadar tertentu. Rusia menganggap protokol tersebut dapat mengganggu pertumbuhan ekonomi. Namun kemajuan yang sangat produktif tercapai pada awal Desember ini dengan ber- gabungnya Rusia sebagai negara pihak aktif menyusul dicapainya kesepakatan dalam sidang parlemen Rusia yang setuju untuk meratifikasi Protokol Kyoto. ${ }^{26}$

Pembicaraan dalam membahas law implementation dari Protokol Kyoto merupakan serangkaian pembicaraan yang panjang yang terdiri dari beberapa Conference of the Parties (COP) dan Meeting of the Parties (MOP). MOP terakhir dilangsungkan di Poznan, Polandia pada bulan November 2008 setelah akhir tahun sebelumnya Indonesia menjadi tuan rumah COP-13 di Nusa Dua Bali. Akhir tahun ini COP-14 akan dilaksanakan di Copenhagen Swedia. Beberapa agenda penting akan dibahas, termasuk upaya melanjutkan konkretisasi the Bali Road Map yang dihasilkan di COP-13 sebagai bagian dalam membahas kerangka kerja adaptasi dan mitigasi perubahan iklim pasca tahun 2012.

Pada pertemuan di Bonn, Jerman bulan Juli 2001 menghasilkan rumusan fundamental yang kemudian dikenal dengan nama Bonn Agreement. Boon Agreement menetapkan beberapa acuan utama dalam program penerapan Protokol Kyoto. Beberapa ketentuan Bonn Agreement membicarakan sistem pendanaan dalam pelaksanaan program terkait Protokol Kyoto, keharusan transfer teknologi dari negara maju ke negara berkembang, dan mekanisme fleksibel yang dapat diterapkan dalam implementasi Protokol Kyoto.

Disebutkan dalam Bonn Agreement bahwa pendanaan di bawah Konvensi Peru-

26 Sumber: http://www.kompas.com/ berita 22 Oktober 2004 dimana kesepakatan majelis rendah Rusia (DUMA) setuju untuk melakukan ratifikasi Protokol Kyoto, namun penyerahan berkas ratifikasi baru dilaksanakan pada tanggal 18 November 2004. 
bahan Iklim Annex I \& II harus menyediakan pendanaan baru bagi negara berkembang, yang sesuai dengan komitmen mereka di dalam konvensi tersebut, melalui lembaga GEF (Global Enviromental Facilities), dana khusus untuk perubahan iklim (special climate change fund), dan lembaga-lembaga donor bilateral dan multilateral. Aktifitas pendanaan ini termasuk di dalamnya untuk $c a$ pacity building, adaptasi (upaya yang dapat dilakukan untuk menekan dampak negatif dari perubahan iklim), alih teknologi, energi, transport, industri, pertanian, kehutanan, manajemen limbah, dan juga aktifitas lainnya untuk membantu negara berkembang mengembangkan perekonomiannya. ${ }^{27}$

Negara-negara maju memberikan komitmennya secara sukarela untuk aktifitas pendanaan ini sebesar kurang lebih US\$ 600 juta sejak tahun 2005. Ketentuan ini ikut dijadikan alasan bagi AS dan Australia atas keengganan mereka menjadi pihak aktif protokol karena dirasakan merugikan satu pihak, yaitu negara maju.

Bonn Agreement juga merumuskan tentang pendanaan di bawah Protokol Kyoto. Ketentuan ini menunjukkan adanya pemberlakuan pembagian tanggung jawab. Untuk itu disediakan dana adaptasi (adaptation fund) untuk membiayai proyek-proyek adaptasi di tiap negara sesuai dengan Protokol. Dana untuk adaptasi ini akan diperoleh dari pembagian hasil dari proyek-proyek CDM (sebesar 2 persen) dan sumber-sumber dana lainnya. Dana ini akan dikelola oleh sebuah

27 Pendanaan untuk berbagai kegiatan ini sebagai pelaksanaan Konvensi Perubahan Iklim Pasal 4.8 $\& 4.9$ yang mensyaratkan adanya berbagai aktifitas yang harus dilakukan negara maju terhadap negara berkembang sebagai respon terhadap dampak perubahan iklim. badan keuangan PBB untuk Konvensi Perubahan Iklim.

Ketentuan mengenai Mekanisme Fleksibel, terdiri dari 3 hal, yaitu Implementasi Bersama (Joint Implementation-JI), Mekanisme Pembangunan Bersih (Clean Development Mechanism-CDM), dan Perdagangan Emisi (Emissions Trading-ET). Mekanisme ini adalah merupakan salah satu cara bagi negara-negara Annex I dalam upayanya menurunkan emisi gas rumah kaca di luar negeri. Penggunaan mekanisme ini oleh negara-negara Annex I hanya bersifat tambahan (supplemental) bagi kegiatan penurunan emisi gas rumah kaca di dalam negeri mereka. Kegiatan menurunkan emisi gas rumah kaca di dalam negeri haruslah merupakan sebuah tindakan yang signifikan atas usaha yang dilakukan oleh tiap negara Annex I dalam rangka memenuhi ketetapan Protokol Kyoto.

Satu kemajuan berarti yang dicapai dalam perumusan Bonn Agreement adalah ketentuan mengenai Tata Guna Lahan dan Kehutanan (LULUCF). Ketentuan mengenai LULUCF mengusulkan bahwa definisi "hutan", "aforestasi”, "reforestasi”, dan “deforestasi" adalah berdasarkan perubahan dalam tata guna lahan. Debet emisi gas rumah kaca selama periode komitmen pertama yang berasal dari hasil panen, aforestasi dan reforestasi sejak tahun 1990 jumlahnya tidak boleh lebih besar dari kredit emisi yang dihasilkan dari daerah yang sama. Tiap negara boleh memilih untuk melaksanakan semua atau beberapa kegiatan tambahan (additional activities) -manajemen hutan, manajemen ladang, manajemen padang rumput dan revegetasi- dalam rangka penurunan emisi 
gas rumah kaca dibawah ketentuan pasal 3.4 (mengenai kegiatan tambahan) Protokol Kyoto.

Untuk menangani masalah kepatuhan (compliance) para negara pihak, Bonn Agreement juga menentukan untuk membentuk Komite Kepatuhan (Compliance Committee) yang meliputi facilitative branch dan enforcement branch. Tujuan komite ini adalah untuk memperbaiki ketidakpatuhan, untuk menjamin integritas lingkungan dan juga untuk memberikan insentif agar mereka patuh.

Fungsi facilitative branch adalah untuk memberikan saran dan memfasilitasi demi terlaksananya kepatuhan, serta memberikan peringatan pendahuluan untuk ketidakpatuhan. Sedangkan enforcement branch adalah badan yang akan menerapkan konsekuensi bagi aktifitas ketidakpatuhan. Tujuan memperbaiki ketidakpatuhan adalah untuk menjamin integritas lingkungan dan juga untuk memberikan insentif agar mereka patuh. Adapun beberapa sanksi dari ketidakpatuhan negara-negara Annex I dalam menjalankan komitmen mereka di dalam Protokol Kyoto, antara lain: menambahkan 1,3 kali dari jumlah emisi negara bersangkutan pada komitmen periode pertama, untuk diberlakukan sebagai jumlah emisi yang ditetapkan untuk komitmen periode kedua; membuat sebuah rencana kepatuhan (compliance action plan); hingga sanksi mendapatkan skorsing untuk tidak melakukan perdagangan emisi.

Sebagai negara yang ikut meratifikasi Protokol Kyoto, Indonesia dapat, dan dalam beberapa kegiatan telah, meraih keuntungan melalui CDM. Melalui mekanisme ini, Indonesia akan diuntungkan dengan hadirnya proyek-proyek ramah lingkungan dengan biaya yang relatif lebih murah; adanya transfer teknologi dari negara maju dengan biaya yang terjangkau; dan terciptanya pembangunan berkelanjutan.

CDM merupakan salah satu mekanisme dalam Protokol Kyoto yang memungkinkan negara maju untuk melakukan penurunan emisi di luar negaranya, melalui usaha penurunan emisi di negara lain. Nantinya, kredit penurunan emisi yang dihasilkan akan dimiliki oleh negara maju tersebut. Selain membantu negara maju dalam memenuhi target penurunan emisi, CDM juga bertujuan membantu negara berkembang dalam mendukung pembangunan berkelanjutan di negara berkembang.

\section{Upaya Pemerintah Indonesia dalam Adaptasi dan Mitigasi Perubahan Iklim}

Kesepakatan yang tercantum dalam Protokol Kyoto mengakomodasi prinsip "common but differentiated responsibilities". Protokol yang dicetuskan dalam COP-3 di KyotoJepang pada Desember 1997 ini, memiliki kekuatan hukum sejak 16 Februari 2004. Secara hukum, Protokol Kyoto mewajibkan agar pada tahun 2008-2012 (Komitmen Periode I) negara-negara Annex-I menurunkan emisi GRK rata-ratanya sebesar 5.2\% dari total emisi dunia tahun 1990.

Protokol Kyoto juga membuka kesempatan bagi negara berkembang untuk berpartisipasi untuk menurunkan emisi GRK melalui Mekanisme Pembangunan Bersih (Clean Development Mechanism, CDM), yang memiliki tujuan: Pertama, kerjasama antara negara maju/industri (Annex-I) dengan negara berkembang (Non-Annex- 
I) dengan prinsip win-win solution; Kedua, untuk membantu kewajiban negara maju dalam menurunkan emisi GRKnya untuk memenuhi komitmen 2008-2012 (Komitmen Pertama); Ketiga, untuk membantu negara berkembang dalam upaya mencapai pembangunan berkelanjutan.

Indonesia telah meratifikasi UNFCCC pada tanggal 1 Agustus 1994 melalui Undang-Undang Nomor 6 Tahun 1994 dan Protokol Kyoto pada tanggal 28 Juli 2004 melalui Undang-Undang Nomor 17 Tahun 2004 serta telah membentuk Designated National Authority (DNA) yaitu Komisi Nasional Mekanisme Pembangunan BersihKNMPB melalui KepmenLH No. 206 Tahun 2005 sehingga secara legal dapat mengikuti mekanisme CDM dalam upaya menurunkan emisi GRKnya. Komisi Nasional ini berperan sebagai otoritas yang ditunjuk untuk memberikan persetujuan nasional bagi pro yek-proyek CDM.

Adaptasi jika dirunut dari asal bahasanya berasal dari kata "adaptation" yang berarti the action or process of adapting or being adapted. ${ }^{28}$ Sedangkan mitigasi berasal dari kata "mitigate" yang dapat diartikan to make something less severe, violent or painful. ${ }^{29}$ Pemaknaan dua kata ini dalam ranah climate change bisa jadi merupakan suatu terobosan hukum baru, dalam hal bahwa upaya hukum yang perlu dilakukan dalam mengatasi dampak perubahan iklim perlu untuk disusun dengan penuh kecermatan, integral dalam semua aspek, dengan pendekatan prinsip kehati-hatian dan berpikir progresif ke depan. Dengan kata lain, pertanyaan yang

\footnotetext{
28 AS. Hornby. (1995). Oxford Advanced Learner's Dictionary: Fifth Edition. Oxford University Press. 29 Ibid.
}

perlu dijawab oleh masing-masing negara dalam dealing the global warming tidak lagi tentang siapa yang perlu bertanggung jawab lebih atau seberapa besar peran dan kewajiban negara untuk mengurangi emisi gas rumah kaca, terutama karbon, tetapi lebih ke arah pertanyaan apakah yang bisa tiap negara lakukan dengan kapasitas masing-masing untuk bersama-sama melakukan langkah dini dalam adaptasi terhadap dampak perubahan iklim.

Di Indonesia sendiri, pelaksanaan upaya mitigasi dan adaptasi dampak perubahan iklim perlu dilakukan secara integral antar semua sektor. Dalam bidang kehutanan semisal, menurut data State of the World's Forests 2007 yang dikeluarkan the United Nations Food \& Agriculture Organizations (FAO), angka deforestasi Indonesia 200020051,8 juta hektar/tahun, ${ }^{30}$ dengan laju deforestasi $2 \%$ per tahun. ${ }^{31}$

Penyebabnya ketidakmampuan aparat penegak hukum untuk mengegakkan aturan untuk menghentikan aksi-aksi destructive logging. Padahal segala dampak nyata akibat kerusakan hutan telah dirasakan, banjir, kekeringan, erosi, longsor, sedimentasi dan sebagainya. Sebagai salah satu dari 44 negara yang secara kolektif memiliki 90 persen hutan di dunia, Indonesia meraih tingkat laju penghancuran tercepat antara $2000-2005$, yakni dengan tingkat 1,871 juta hektar atau sebesar 2 persen setiap tahun atau 51 kilo-

$30 \quad$ FAO State of World Forest 2007. Available online at: $\quad$ www.fao.org/docrep/009/a0773e/a0773e00. HTM Diakses tanggal 10 Juli 2008

31 Brazil dalam kurun waktu yang sama dengan jumlah 3,1 juta hektar/tahun merupakan kawasan deforestasi terbesar di dunia. Namun karena luas kawasan hutan total Indonesia jauh lebih kecil daripada Brasil, maka laju deforestasi Indonesia menjadi jauh lebih besar. Laju deforestasi Brasil hanya $0.6 \%$. 
meter persegi per hari, atau setara dengan 300 lapangan bola setiap jamnya. Padahal tingkat kerusakan tersebut merujuk pada data FAO yang bersifat konservatif. ${ }^{32}$

Angka kehancuran Indonesia tersebut merupakan yang tertinggi dari 43 negara lain, disusul oleh Zimbabwe setiap tahun sebesar 1,7 persen dari luas hutan tersisa, Myanmar 1,4 persen, dan Brazil hanya 0,6 persen. Kerusakan hutan Indonesia tersebut sebaliknya telah menyelamatkan hutan Cina sebagai negara tujuan ekspor produk kayu terbesar dari Indonesia. Luas hutan Cina setiap tahun malah bertambah luas 2,2 persen. Sebaliknya Indonesia saat ini hanya menyisakan 28 persen hutan primernya. ${ }^{33}$

Hutan primer tersisa, menurut data KLH yang dilansir pada pertengahan tahun 2006, telah menurun drastis. Hutan tersisa berdasarkan citra satelit di Jawa tinggal 19 persen, Kalimantan 19 persen, dan Sumatera 25 persen; jauh di bawah angka 30 persen, yakni luas hutan tersisa di suatu pulau yang diijinkan oleh Undang-Undang Nomor 41 Tahun 1999 tentang Kehutanan. Sedangkan hutan tersisa yang berada di atas tingkat tersebut adalah Papua (71 persen), Sulawesi (43 persen), dan Bali (22 persen). Sedangkan hutan bakau (mangrove) yang tersisa hanyalah 30 persen dari seluruh hutan bakau yang ada di tanah air sebelumnya. Bahkan saat ini 43 juta hektar area hutan telah menjadi lahan kritis.

Sementara itu, saat Indonesia mengalami krisis kehutanan yang berkepanjangan, pemerintah Indonesia juga telah berhasil dengan sukses menyelenggarakan perhelatan

$32 \quad$ FAO State of World Forest 2007.

33 Ibid. akbar dunia dalam pembahasan tentang isu pemanasan global. Pertemuan para pemimpin dunia di Bali yang bernama Conference of the Parties (COP-13) itu telah menghasilkan keputusan tentang pengurangan emisi dari deforestasi dan degradasi (REDD) di negara berkembang. REDD juga merupakan bagian penting dari aksi mitigasi perubahan iklim dalam "Bali Action Plan". 34 Dalam "Bali Action Plan", disamping negara maju yang harus memenuhi kewajiban peningkatan target penurunan emisi dan membantu negara berkembang dalam upaya mengurangi dampak negatif perubahan iklim, negara berkembang juga didorong melakukan aksi nyata dalam upaya mitigasi dan adaptasi terhadap perubahan iklim dalam konteks pembangunan berkelanjutan, antara lain melalui integrasi upaya adaptasi dan mitigasi perubahan iklim kedalam perencanaan nasional dan sectoral planning. ${ }^{35}$

Pada dasarnya, strategi antisipasi, adaptasi dan mitigasi perubahan iklim tidak hanya memiliki dimensi teknis, tapi juga memiliki dimensi struktural dan kelembagaan dengan cara memanfaatkan inovasi teknologi, inovasi sosial kelembagaan dan kearifan lokal yang berkembang di tengah masyarakat. Dalam pembahasan ini, dapat terlihat bahwa pendekatan adaptasi dan mitigasi per-ubahan iklim perlu untuk dilakukan dalam berbagai sektor, yang mana masingmasing sektor di Indonesia masih memiliki arogansi sendiri-sendiri. Sektor kehutanan yang mendapat porsi perhatian tersendiri

\footnotetext{
34 Anonim, 24 Maret 2008, Pengurangan Emisi dari Deforeatsi dan Degradasi Hutan di Indonesia (Reducing Emissions From Deforestation and Forest Degradation in Indonesia/REDDI), Source: www.ifca.com. Diakses 16 Juli 2008

35 Ibid.
} 
dari UNFCCC perlu untuk dimaknai oleh Pemerintah sebagai upaya untuk melakukan adaptasi dan mitigasi terhadap perubahan iklim dengan mereformulasi kebijakan kehutanan secara integral, sehingga memiliki visi lingkungan yang sejalan dengan semangat mengurangi dampak perubahan iklim dan pemanasan global.

Fokus mitigasi perubahan iklim dalam sektor kehutanan akan sedikit diulas dalam bahasan tersendiri terkait penerapan REDD+ di Indonesia. Dalam sektor lainnya yang cukup dekat adalah di bidang pertanian dan perikanan. Dalam bidang pertanian, salah satu aspek mendasar yang diterapkan dalam mitigasi perubahan iklim nampak pada kebijakan yang terkait penghentian dan pembatasan perubahan fungsi lahan pertanian (land-use changing). Beberapa penerapannya nampak pada regulasi dan kebijakan yang dihasilkan oleh sistem legislasi nasional. Sekurangnya, dengan adanya UndangUndang Nomor 41 Tahun 2009 tentang Perlindungan Lahan Pertanian Pangan Berkelanjutan dan Undang-Undang Nomor 19 Tahun 2013 tentang Perlindungan dan Pemberdayaan Petani, memberikan penegasan tentang kewajiban dan peran negara dalam upaya adaptasi dan mitigasi perubahan iklim dalam sektor pertanian. Dalam level operasionalnya, kebijakan moratorium sementara pemanfaatan lahan gambut melalui Surat Edaran Menteri Pertanian Nomor 321 Tahun 2007 juga menunjukkan arah penguatan dalam adaptasi perubahan iklim.

Di dalam bidang perikanan, dampak perubahan iklim terhadap budidaya perikanan bisa secara langsung dapat mengubah fisiologi, perilaku dan pertumbuhan, kemampuan reproduksi, kematian ikan, dan produktivitas. Secara tidak langsung, perubahan iklim dapat mengubah ekosistem aquatic sebagai tempat hidup, stok dan suplai ikan, barang dan jasa yang diperlukan dalam budidaya perikanan. ${ }^{36}$

Atas permasalahan itulah, adaptasi dan mitigasi sangat diperlukan pada skala yang sesuai pada tingkat individu, keluarga, institusi pemerintah, baik lokal, nasional dan global, dengan menetapkan rencana penanganan dalam jangka pendek, menengah, dan panjang. Penanganan dampak perubahan cuaca pada dasarnya untuk menjamin ketersediaan pangan dan pembangunan yang berkelanjutan. Selain itu, diperlukan juga pertumbuhan jangka panjang industri budidaya perikanan. ${ }^{37}$

\section{REDD+ dan Peran Indonesia}

REDD awalnya hanya menyangkut upaya pencegahan deforestasi dan degradasi hutan, aspek negatif dalam skema ini. Mengingat skema REDD juga perlu disusupi dengan aspek positif berupa pengelolaan hutan lestari (sustainable forest management), konservasi dan peningkatan penyimpanan karbon (carbon stock), maka dalam perkembangan skema REDD kemudian ditambah dengan "+" di huruf terakhirnya sehingga menjadi Reducing Emission by Deforestation and Forest Degradation, Carbon Stock Enhancement and Forest Conservation (REDD+). ${ }^{38}$

Pada dasarnya REDD+ merupakan mekanisme yang dibangun oleh masyarakat

36 Paparan dari Prof. Dr. Ir. Rustadi, M.Sc., dalam Seminar Nasional Tahunan VIII Hasil Penelitian Kelautan dan Perikanan, Auditorium Fakultas Pertanian UGM, 16 Juli 2014.

Ibid.

38 Perubahan menjadi REDD + merupakan hasil perundingan di COP ke 14 di Poznan. 
internasional guna mencegah terjadinya kerusakan hutan berupa deforestasi atau degradasi yang berkontribusi nyata terhadap peningkatan GRK di dunia. ${ }^{39}$ Ia berupa mekanisme global untuk memberikan suatu insentif bagi negara-negara berkembang untuk melindungi dan mengelola sumber daya hutannya dengan lebih baik dan bijaksana serta memberikan kontribusi terhadap perjuangan global melawan perubahan iklim. Strategi yang dibuat dalam REDD+ bertujuan untuk membuat hutan lebih bernilai dari pada ketika hutan tersebut ditebang.

Program ini dibuat karena menyadari bahwa berkurangnya hutan memegang peranan dalam pemanasan global. Kontribusi hutan sebagai penyumbang sekaligus penyerap emisi gas rumah kaca sudah mulai disinggung pada tahun 2001 dalam sebuah laporan dari Intergovernmental Panel on Climate Change (IPCC). Laporan yang dikenal sebagai Third Assesment Report (TAR) ini menyebutkan kontribusi perubahan tata guna lahan pada perubahan iklim sejak dekade 1980-an hingga tahun 2001 berjumlah kurang lebih seperempat dari emisi global yang ada waktu itu. Adapun penyumbang terbesar dari perubahan tata guna lahan itu adalah deforestasi. ${ }^{40}$

39 Saat ini, emisi tataguna lahan menyumbang hampir seperlima (sekitar 6 GT) total emisi dunia, dan hampir seluruhnya terjadi karena deforestasi dan perusakan hutan. Setengah dari emisi ini dihasilkan hanya oleh dua negara, yaitu Indonesia dan Brazil. Indonesia menghasilkan emisi dari deforestasi dan pengrusakan hutan duakali lipat dari Brazil, sehingga deforestasi di Indonesia menyumbang sekitar sepertiga total emisi dari deforestasi dan pengrusakan hutan, atau sekitar tujuh persen total emisi dunia.

40 TAR yang dikeluarkan oleh IPCC ini menginisiasi lahirnya sebuah dokumen UNFCCC yang dihasilkan di dalam COP 7 tahun 2001 yang diselenggarakan di Marrakesh, Maroko, yang dikenal dengan nama "Marrakesh Accord". Dokumen ini antara lain memasukkan hutan dalam strategi mitigasi per-
Ketertarikan Indonesia untuk ikut dalam program tersebut ditunjukkan dengan komitmen Presiden Indonesia untuk mengurangi emisi sebesar $26 \%$ dengan usaha sendiri dan $41 \%$ dengan bantuan pihak asing. ${ }^{41}$ Komitmen tersebut mengundang Norwegia untuk mengikat kerjasama dengan Indonesia melalui sebuah pernyataan niat (Letter of Intent) pada tahun 2010. Menanggapi dukungan Norwegia tersebut, pemerintah Indonesia mengeluarkan beberapa kebijakan untuk mendukung pelaksanaan REDD + . Kebijakan tersebut antara lain keputusan Presiden Republik Indonesia Nomor 19 Tahun 2010 Tentang Satuan Tugas Persiapan Pembentukan Kelembagaan REDD+, yang berakhir masa tugasnya pada tanggal 30 Juni 2011. Hasil Satgas REDD+ pertama ini antara lain adalah dokumen Strategi Nasional REDD+ yang telah dikonsultasikan secara luas dengan berbagai pihak, Inpres. No. 10 Tahun 2011 tentang Penundaan Pemberian Izin Baru dan Penyempurnaan Tata Kelola Hutan Alam Primer dan Lahan Gambut, serta diseleksi dan disiapkannya Provinsi Kalimantan

ubahan iklim. Namun dalam perundingan, hanya aspek reforestasi dan aforestasi saja yang dimasukkan ke dalam skema mitigasi, yang kemudian dimasukkan ke dalam Skema CDM dalam Protokol Kyoto. Sementara itu, pencegahan deforestasi yang sebenarnya penyebab utama perubahan iklimtidak dibahas. Penyebabnya, antara lain, adalah masalah definisi hutan yang masih ambigu dan lingkup CDM hanya berupa proyek yang kecil, sementara deforestasi lingkupnya secara geografi lebih luas. Mumu Huhajir, Op. Cit., hlm. 3

41 Dalam latar belakang STRANAS REDD menyebutkan tentang komitmen Indonesia untuk menurunkan emisi sebesar 26 persen dari scenario pembangunan Bussiness as Usual (BAU) pada tahun 2020 dengan dana sendiri tanpa mengorbankan pembangunan di sektor lain, atau 41 persen jika mendapatkan bantuan internasional. Komitmen ini disampaikan oleh Presiden Susilo Bambang Yudoyono pada pertemuan G20 september 2009 di Bangkok lihat: Indonesia $\mathrm{CO} 2$ pledge to help climate talksgreens, http://www.reuters.com/article/2009/09/29/ idUSSP 495601, akses pada tanggal 29 Juli 2012 
Tengah sebagai Provinsi Pilot REDD+ yang pertama di Indonesia. ${ }^{42}$

Upaya implementasi REDD+ di Kalimantan Tengah mempunyai tantangan yang besar. Persoalan illegal logging yang mewabah di hampir seluruh wilayah Indonesia juga terjadi di Kalimantan Tengah. ${ }^{43}$ Di Kalimantan Tengah, illegal logging bahkan dilakukan di wilayah konservasi hutan. Wilayah sekitar Taman Nasional Sebangau selama ini dikenal kerap menjadi sasaran utama bagi para pembalak liar, mengingat hutan nya masih memiliki potensi kayu yang sangat besar dengan fungsinya sebagai kawasan konservasi. Pada tahun 2007, sedikitnya satu juta potong kayu ilegal dibabat yang sebagian besar berasal dari Taman Nasional Sebangau dan sisanya dari kawasan hutan di sekitarnya. ${ }^{44}$

42 Booklet Satgas REDD+, http://www.satgasredd plus.org/download/Booklet.Satgas.REDD+.pdf, Diakses pada tanggal 29 Juli 2012

43 Laporan World Resource (2005) yang dimuat dalam Koran Harian Kompas tanggal 31 oktober 2006 melaporkan, dalam kurun waktu 20 tahun kerusakan hutan di Indonesia telah mencapai 43 juta hektar atau setara dengan seluruh luas gabungan negara Jerman dan Belanda. Tuti Budi Utami, 2007, Kebijakan Hukum Pidana Dalam Menanggulangi Tindak Pidana Illegal logging, Tesis, Semarang: Universitas Diponegoro, Pada Juni 2004 pun World Bank kemudian menyatakan bahwa setiap detik pohon-pohon hutan Indonesia ditebangi secara liar. Per menitnya mencapai 6 kali luas lapangan bola dan kerugian per tahun mencapai 31 (tiga puluh satu) triliun rupiah. World Bank mencatat, kerusakan sebelum era reformasi hutan tidak mencapai jutaan hektar per tahun, sedangkan di era reformasi justru rata-rata kerusakan hutan mencapai 3,8 juta hektar per tahun. Angka ini kurang lebih sama dengan besarnya negara Swiss. Studi Indonesia Corruption Watch (ICW) selama kurun waktu 2004-2010, kerugian negara akibat pembalakan hutan di Indonesia mencapai Rp 169,7 triliun. Nilai sebesar itu diperoleh dari perhitungan kekurangan penerimaan negara dari sektor pajak bumi dan bangunan serta sejumlah perijinan dan royalti. Menghitung kerugian negara akibat illegal logging, Mouna Wasef. Diakses 29 Juli 2012.

44 Wilayah sekitar Taman Nasional Sebangau selama ini dikenal kerap menjadi sasaran utama bagi para pembalak liar mengingat hutannya yang
Kesiapan aparat dalam menangani kasus illegal logging di Kalimantan Tengah tentunya menjadi salah satu bahan pertimbangan keberhasilan implementasi REDD+ di Kalimantan Tengah. Hal ini sejalan dengan Strategi Nasional/STRANAS REDD+ yang telah diluncurkan pada bulan Juli 2012. Kerangka strategi REDD+ dibangun untuk mencapai tujuan jangka panjang, yaitu:

a. Menurunkan emisi gas rumah kaca yang berasal dari sector pengguna lahan dan perubahannya, serta kehutanan (Land Use and Land Use Change and Forestry/LULUCF);

b. Meningkatkan simpanan karbon;

c. Meningkatkan kelestarian keanekaragaman hayati;

d. Meningkatkan nilai dan keberlanjutan fungsi ekonomi hutan.

Kerangka kerja dalam STRANAS REDD+ tersebut terdiri dari lima pilar yang saling berhubungan. Kelima pilar tersebut antara lain:

a. Pembangunan sistem kelembagaan REDD+;

b. Pengkajian ulang serta penguatan kebijakan dan peraturan;

c. Peluncuran program-program strategis;

d. Perubahan paradigma dan budaya kerja;

e. Pelibatan para pihak.

Upaya pengefektifan penegakan hukum masuk dalam pilar kedua. Penegakan hukum secara tegas dan konsisten terhadap pelanggaran-pelanggaran aturan pelaksanaan izin pemanfaatan hutan menjadi salah satu poin penting dalam pilar tersebut. Kebijakan yang dirancang untuk melaksanakan

masih memiliki potensi kayu sangat besar dengan fungsinya sebagai kawasan konservasi. 
poin tersebut antara lain pembentukan dan penguatan kapasitas jaksa dan polisi lingkungan satu atap (One Roof Enforcement System/ORES). Poin penting lainnya dalam pilar kedua ini adalah pengefektifan moratorium penebangan. Melalui Inpres Nomor 10 Tahun 2011 tentang Penundaan Pemberian Izin Baru dan Penyempurnaan Tata Kelola Hutan Alam Primer dan Lahan Gambut, pemerintah bermaksud untuk menyeimbangkan dan menyelaraskan pembangunan ekonomi nasional dengan upaya penurunan gas emisi rumah kaca dari sektor berbasis kelola lahan. Terkait dengan hal itu penegakan hukum atas izin-izin yang telah diterbitkan yang tidak sesuai dengan prosedur dan ketentuan yang berlaku harus dilakukan secara optimal.

Kebijakan implementasi REDD + dalam ranah hukum tentunya harus digagas secara matang. Kematangan konsep kebijakan di tingkat pusat maupun daerah menjadi salah satu hal dalam yang esesnsial dalam penegakan hukum untuk mendukung REDD+ di Kalimantan Tengah. Lebih dari itu, konsep tersebut tentunya harus didukung pula oleh kesiapan para aparat penegak hukum illegal logging. Aparat penegak hukum diharapkan memiliki kinerja dan kerjasama yang baik dalam bidang penyidikan dan penuntutan kasus illegal logging. Selain itu, aparat juga harus mempunyai kepedulian terhadap penyelamatan lingkungan global, khususnya hutan serta pengetahuan tentang REDD+.

\section{PENUTUP}

Dampak perubahan iklim global sebenarnya sudah mulai nampak sejak lima puluh tahun terakhir. Berdasarkan data 1970-2004 yang dikumpulkan oleh Intergovermental Panel on Climate Change (IPCC) menunjukkan, bahwa suhu bumi mengalami peningkatan rata-rata $0,20 \mathrm{C}$ per tahun. Periode tahun 2001-2010 tercatat sebagai periode sepuluh tahun terpanas sejak pertama kali pencatatan cuaca dilakukan pada 1850 . Demikian juga halnya dengan suhu lautan yang turut memanas sejak pertengahan abad-20, sehingga menyebabkan mencairnya raksasa gunung es secara masif di Lautan Artik (Kutub Utara) dan di Lautan Antartika (Kutub Selatan), yang selanjutnya mengakibatkan peningkatan permukaan laut dari $-20 \mathrm{~cm}$ pada 1950 menjadi $+5 \mathrm{~cm}$ pada tahun 2000 . Selain itu, perubahan iklim global juga telah mengakibatkan pola iklim menjadi tidak teratur, cuaca ekstrim, musim penghujan menjadi lebih panjang dengan curah hujan yang tinggi, demikian juga musim kemarau, banjir, longsor, gelombang panas, peledakan wabah penyakit, pengikisan keanekaragaman hayati), dan penurunan produksi pangan di berbagai belahan dunia.

Potensi dan dampak yang besar inilah yang menjadi dasar pertimbangan bahwa penanggulangan (mitigasi) dan antisipasi (adaptasi) secara preventif maupun kuratif sangatlah diperlukan. Dalam simpulan ini, proses adaptasi dan mitigasi ini diperlukan melalui konteks pendekatan protektif dengan membuat perlindungan, pendekatan akomodatif atau melakukan penyesuaian baik secara fisik maupun sosial-ekonomi dan budaya hidup, serta dengan pola retreat dengan bertahan terhadap dampak yang muncul. Dalam level regulasi dan kebijakan pun, Indonesia cukup memiliki kerangka hukum yang mewadahi poin tersebut. 


\section{BIBLIOGRAFI}

A.S. Hornby. (1995). Oxford Advanced Learner's Dictionary: Fifth Edition. UK: Oxford University Press.

Bell, Stuart. and McGillivrey, Donald (ed.). (2006), Environmental Law, London: Oxford University Press.

Birnie, P.W., and Boyle, A.E. (1995). Basic Documents on International Law and the Environment, Oxford: Clarendon Press.

Boyd, Emily., and Schipper, Emma. (2002). "Marrakech Accord-at the Crossroad to Ratification: Seventh Conference of the Parties to United Nations Framework Convention on Climate Change". Journal of Environment Development, 11: 184-191.

Faure, Michael., Gupta, Joyeeta. and Nentjes, Andries (ed.). (2003). Climate Change and the Kyoto Protocols: the Role of Institution and Instrument to Control Global Change, Glos UK: Edward Elgar Publishing Ltd.

Sands, Philippe. (2003). Principle of International Environmental Law: Second Edition, Cambridge UK: Cambridge University Press.

\section{Peraturan Perundang-undangan}

The United Nations Framework Convention on Climate Change 1992 (UNFCCC).

The Kyoto Protocols to the UNFCCC.

Undang-Undang Nomor 6 Tahun 1994 tentang Ratifikasi Terhadap United $\mathrm{Na}$ tions Framework Convention on Climate Change 1992 (UNFCCC).

Undang-Undang Nomor 23 Tahun 1997 tentang Pengelolaan Lingkungan Hidup
Undang-Undang Nomor 17 Tahun 2004 tentang Ratifikasi Terhadap Kyoto Protocol.

Undang-Undang Nomor 19 Tahun 2004 jo. Undang-Undang Nomor 41 Tahun 1999 tentang Kehutanan

Undang-Undang Nomor 32 Tahun 2009 tentang Perlindungan dan Pengelolaan Lingkungan Hidup

\section{Sumber lainnya}

Anonim. (2008). Pengurangan Emisi dari Deforeatsi dan Degradasi Hutan di Indonesia (Reducing Emissions from Deforestation and Forest Degradation in Indonesia/REDDI), Source: www. ifca.com. Diakses 16 Juli 2008

Asian Development Bank. (2006). Asian Development Outlook 2006. Hongkong: ADB Publisher.

Booklet Satgas REDD+, http://www.satgasreddplus.org/download/Booklet. Satgas.REDD+.pdf, akses pada tanggal 29 Juli 2012

FAO. (2007). State of World Forest 2007. diunduh dari www.fao.org/docrep/009/ a0773e/a0773e00.HTM

Indonesia $\mathrm{CO} 2$ Pledge to Help Climate Talks-greens, http://www.reuters.com/ article/2009/09/29/idUSSP495601, Diakses pada tanggal 29 Juli 2012.

IPPC, Fourth Assessment Report: Climate Change 2007. Available online at: http://www.wmo.ch/pages/partners/ ipcc/index en.html.

Ministry of Environment Republic of Indonesia. (2001). National Strategy Study on the Clean Development Mechanism in Indonesia, Jakarta: KLH. 
Ministry of Environment Republic of Indonesia. (2004). National Strategy Study on CDM in Forestry Sector - a Technical Report, Jakarta: KLH.

NEDO - New Energy and Industrial Technology Development Organization. (2006). CDM Development in Indonesia - Enabling Policies, Institutions and Programs, Issues and Challenges (a Compilation), Jakarta:
NEDO, available online at http:// www.nedojakarta.org/nedo/html/docs/ cdm.pdf

United Nations Environment Programme (UNEP) and the Climate Change Secretariat (UNFCCC). (2002). Understanding Climate Change: a Beginner's Guide to the UN Framework Convention and Its Kyoto Protocol. Booklet UNEP-Jeneva. 